\title{
ПРИЧИНЫ СОВЕРШЕНИЯ ПРЕСТУПЛЕНИЙ С ИСПОЛЬЗОВАНИЕМ БЕСПИЛОТНЫХ ЛЕТАТЕЛЬНЫХ АППАРАТОВ
}

\section{THE CAUSES OF CRIME WITH THE USE OF UNMANNED AERIAL VEHICLES}

V. Giba

P. Agapov

Summary: The experience of using unmanned aerial vehicles in military operations in the Persian Gulf, Yugoslavia, the middle East, and other regions has proved their high efficiency, feasibility, and reliability. Such devices have been widely implemented in geophysical exploration, mapping, search and rescue operations, construction, Commerce, etc. At the same time, unmanned aerial vehicles were actively used for illegal purposes. In this article, the author attempts to identify the main reasons that contribute to the Commission of crimes using drones, in order to form an idea of a possible system for countering such crimes.

Keywords: unmanned aerial vehicle, UAV, UAV, drone, crime, crime, counteraction.
Гиба Владислав Владимирович

Аспирант, РУТ (МИИТ)

vlad-giba@mail.ru

Агапов Павел Валерьевич к.ю.н., дочент, РУТ (МИИТ)

Аннотация: Опыт применения беспилотных летательных аппаратов в в0енных операциях в Персидском заливе, в Югославии, на Ближнем Востоке и др. регионах доказал их высокую эффективность, целесообразность, надежность. Такие аппараты начали широко внедрять в геофизической разведке, картографировании, поисково-спасательных операциях, строительстве, коммерции и т.д. Одновременно с этим беспилотные летательные аппараты стали активно использовать и в противоправных целях. В настоящей статье автором предпринята попытка выявить основные причины, способствующие совершению преступлений с помощью беспилотников, для того чтобы сформировать представление о возможной системе противодействия таким преступлениям.

Ключевые слова: беспилотный летательный аппарат, беспилотник, БПЛА, дрон, преступление, преступность, противодействие.

ва, в настоящее время признана реальной угроза применения беспилотных летательных аппаратов в любой точке мира в преступных, в том числе, в террористических целях [14]. Яркий пример преступления, совершенного с помощью беспилотного летательного аппарата, - покушение в августе 2018 г. на президента Венесуэлы Николаса Мадуро во время его выступления на военном параде (в итоге ранения от взрывчатки, заложенной в БПЛА, получили семь солдат).

В «Большую российскую энциклопедию» включено такое определение БПЛА: «это искусственный мобильный объект (летательный аппарат), как правило, многоразового использования, не имеющий на борту экипажа (человека-пилота), способный, при этом, самостоятельно целенаправленно перемещаться в воздухе для выполнения различных функций в автономном режиме (с помощью собственной управляющей программы) или посредством дистанционного управления (осуществляемого человеком-оператором со стационарного или мобильного пульта управления)» [5].

БПЛА, разработанные, в первую очередь, в военных целях, в последние годы стали всё активнее проникать в обыденную жизнь. Гражданские БПЛА уже получили широкое коммерческое использование в: энергетике, строительстве, сельском хозяйстве, услугах по доставке товаров и пр., при ежегодно регистрируемом росте рынка. Аналитики банка «Barclays» подсчитали, что в 2018 г. объем рынка коммерческих беспилотников со- 
ставил 4 млрд. долл., и спрогнозировали его увеличение в ближайшие пять лет в десять раз - до 40 млрд. долл. [16]. Особенно спрос на БПЛА проявился в условиях пандемии COVID-19, когда с их помощью производились: наблюдение за общественными местами, дезинфекция территорий, оповещение населения, транспортировка медикаментов, проб на коронавирус и их результатов.

С течением времени такие черты БПЛА, как высокая стоимость и трудоемкость технологий создания и управления, перестали носить основополагающий характер. Так, А.С. Костиным и Н.В. Богатовым в 2019 г. было отмечено рекордное поступление на рынок сотен тысяч и даже миллионов постоянно дешевеющих потребительских дронов, не уступающих по своему функционалу дронам коммерческого типа [10, с. 66]. Авторское изучение предложений, представленных на сайтах крупнейших российских продавцов электроники («Эльдорадо», «М Видео», «ДНС» и др.), позволяет прийти к выводу о том, что радиоуправляемый квадрокоптер, со встроенной видеокамерой, скоростью полета около 45 км/ч и его допустимой дальностью до 2 км, можно приобрести за сумму в 40000 - 50000 рублей, причем сделать это может любой человек из любой точки страны, даже без необходимости личного посещения магазина.

Высокая распространённость БПЛА, их доступность для широких масс населения, как представляется, - это одно из основных условий роста изучаемой группы преступлений. С.В. Краснов, С.Р. Малышев, С.А. Краснова и B.А. Шишков справедливо указывают на то, что растущие технические возможности при ценовой доступности малогабаритных БПЛА позволяют ожидать «всплеска» целого спектра противоправных действий [11, с. 49]. А.В. Демидюк и А.П. Фомин подмечают, при этом, что наблюдаемые сегодня масштабные продажи БПЛА напрямую повышают степень потенциальных угроз, особенно, для крупных городов, имеющих сложную инфраструктуру и высокую концентрацию мест массового пребывания людей [7]. Обозначенная проблема ещё более усиливается на фоне недостаточного уровня государственного контроля за сферой применения гражданских (коммерческих, потребительских) БПЛА. В нашей стране, равно как и во многих других современных государствах, система регистрации беспилотников переживает стадию становления, а потому является несовершенной.

К примеру, если обратить внимание на введенный с 27 сентября 2019 г. в Российской Федерации механизм учета БПЛА (официально применяемое название - «беспилотные гражданские воздушные суда»), то в нём можно обнаружить следующие изъяны:

Правила учета беспилотных гражданских воздушных судов, утверждённые Постановлением Правительства РФ от 25 мая 2019 г. № 658 [3], в целях определения беспилотных летательных аппаратов, подлежащих реги- страции, оперируют термином «максимальная взлётная масса». Ориентируясь на данный показатель, выделяют три типа БПЛА - имеющие максимальную взлётную массу до 250 г; имеющие максимальную взлётную массу от 250 г до 30 кг; имеющие максимальную взлётную массу свыше 30 кг. Первая группа БПЛА не нуждается ни в регистрации, ни в постановке на учёт. Правда, они, как и все БПЛА, подпадают под действие правил, касающихся использования воздушного пространства и безопасного проведения полётов. Третья группа БПЛА подлежит государственной регистрации, наравне с пилотируемыми летательными аппаратами. Помимо этого, на БПЛА указанной категории распространяются требования: об обязательном оформлении сертификата летной годности (ст. 36 Воздушного кодекса РФ [2]); а также о необходимости получения лицами, которые обслуживают летательный аппарат и управляют им, летных свидетельств (ст.,ст. 53, 57 Воздушного кодекса РФ [2]). Что касается, БПЛА, относимых ко второй группе (самой распространенной в коммерческом и потребительском секторах), то их государство (в лице Федерального агентства воздушного транспорта, Росавиации) учитывает.

Согласно действующей с 27 сентября 2019 г. процедуре, для осуществления учёта БПЛА с максимальной взлётной массой от 250 г до 30 кг его правообладателю необходимо в течение 10 дней с момента приобретения или ввоза на территорию РФ подать заявление в Росавиацию заказным письмом или через портал «Госуслуги» (заявление о ранее приобретённом или ввезённом БПЛА надлежало сдать до 27 октября 2019 г.). В случае положительного решения заявителю направляется уведомление, содержащее регистрационный номер БПЛА, который в обязательном порядке следует на него нанести.

По мнению экспертов, наибольшую сложность в соблюдении описанных выше правил вызывает определение максимальной взлётной массы БПЛА обычными пользователями [4]. На сегодняшний день ни один из популярных любительских беспилотников (к примеру, DJ Phantom 4 Pro, YUNEEC Typhoon H520 или Autel Robotics EVO) не содержит указанный параметр. Как правило, техническая документация оперирует исключительно сведениями о весе самого беспилотника, в лучшем случае с учетом установленных аккумуляторов и пропеллеров. Скорее всего, подразумевается, что бо́льшая часть потребительских БПЛА не предназначена для подъёма какого-либо груза, следовательно, в целях установления максимальной взлётной массы такого аппарата должна учитываться только его масса. Можно предположить, что в ближайшей перспективе производители БПЛА, ориентированные на российский рынок, станут вносить такой параметр, как максимальная взлётная масса, в свои спецификации (тем более, что она теперь является необходимым условием для регистрации или учёта БПЛА). В противном случае можно допустить ситуации, при которых, пользуясь данной законодательной «ла- 
зейкой», владельцы БПЛА будут сознательно избегать установленную процедуру регистрации/учёта.

При всем при этом, нельзя сбрасывать со счетов наличие на рынке не только БПЛА в виде готовых изделий, но и компонентов БПЛА, допускающих возможность сборки любительских летательных аппаратов, имеющих произвольные параметры [8, с. 48]. Тем самым, риск использования неучтённых БПЛА ещё более повышается.

И всё это в условиях отсутствия ответственности за непостановку на учёт БПЛА, имеющих максимальную взлётную массу от 250 г до 30 кг. Для сравнения, несвоевременная регистрация (позже 10 дней с момента приобретения, ввоза) автомобиля в ГИБДД влечёт за собой наложение штрафа в размере от 1500 до 10000 рублей в соответствии со ст. 19.22 КоАП РФ [1]. Возможность привлечения к ответственности за использование неучтённых БПЛА возникает лишь при выявлении несанкционированных полётов, и применению здесь подлежит Ст. 11.4 КоАП РФ [1] - нарушение правил использования воздушного пространства.

Учитывая вышеизложенное, можно высказать предположение о том, что противодействию преступлениям, совершаемым с помощью БПЛА, будет способствовать реализация уже сформулированных в научной среде рекомендаций о необходимости изменения порядка учёта беспилотников с максимальной взлётной массой от 250 граммов до 30 килограммов. В частности, предлагается введение обязательного лицензирования, предшествующего приобретению БПЛА, - в случае отсутствия у гражданина специальной лицензии на использование БПЛА продавец должен отказывать ему в продаже [18]. Правда, учитывая, что практическое применение таких правил - это отдалённая перспектива, сегодня видится уместным обязать магазины подавать в Росавиацию сведения обо всех фактах реализации БПЛА (например, посредством электронного обмена данными, используя, в частности, опыт электронного декларирования).

Помимо описанных выше причин привлекательность БПЛА в качестве средств совершения преступлений обуславливается проблематичностью выявления фигуры исполнителя - оператора беспилотника.

Правы А.В. Демидюк и А.П. Фомин, когда пишут о том, что анонимность, личная безопасность исполнителя преступления, его возможность избежать ответственности - один из ключевых факторов планирования, подготовки и проведения практически любой противоправной акции. И именно дроны позволяют осуществить это в максимальной степени - в условиях плотной городской застройки, при высоком уровне насыщенности «эфира» сигналами различных радиочастот, обнаружение опе- ратора дрона, точки его дислокации становится крайне сложной задачей [7]. Аналогичным образом (удалённостью исполнителя от места совершения преступления) объясняются проблемы доказывания причастности конкретных лиц к совершению преступлений с использованием БПЛА, если уголовные дела по таким преступлениям всё же возбуждаются и расследуются.

Допуская, что с определённой долей условности рассматриваемую категорию преступлений можно отнести к киберпреступности, применимым будет утверждение о том, что противоправные деяния, совершаемые в сфере информационных технологий, характеризуют: высокая латентность, низкая выявляемость и раскрываемость, слабые возможности идентификации злоумышленников $[6$, с. 748; 9]. Объясняются указанные тенденции тем, что «действующая в нашей стране правоохранительная система настроена на реагирования на традиционные виды преступлений, а система противодействия киберпреступности переживает начальный этап своего развития» [15, с. 31]. Следователям и оперативным сотрудникам, имеющим недостаточную квалификацию в IT-сфере, противостоят преступники, оснащённые по последнему слову техники. Последние имеют возможность привлекать в свою деятельность высококлассных специалистов, причём не столько на этапе совершения преступлений, сколько на стадии их подготовки. Известно, что путём внесения изменений в заводские настройки беспилотника могут быть увеличены длительность и дальность его полета, полезная нагрузка и т.д.

Не вызывает сомнения, что совершение любого преступления с использованием БПЛА подразумевает наличие у преступника (исполнителя, организатора, заказчика) специальных навыков и знаний в области ITтехнологий, с их помощью они не только осуществляют задуманное преступное деяние, но и скрывают его следы. Такие лица могут длительное время избегать ответственности, продолжая в условиях безнаказанности совершать новые тождественные преступления [12, с. 55]. Именно на их установление должна быть направлена деятельность правоохранительных органов.

В целом же, перед государством сегодня стоит задача, как можно скорее разработать и принять специальную федеральную программу, предусматривающую реализацию комплекса взаимоувязанных мер правового, организационного и технического регулирования, направленных на противодействие киберпреступлениям, в том числе, преступлениям, совершаемым с помощью БПЛА. Причем, в данной программе должны быть отражены названные выше причины и условия, способствующие и, даже, провоцирующие проведение с использованием БПЛА противоправных акций самого разного характера (от неумышленных и элементарно хулиганских до террористических или диверсионных). 
ЛИТЕРАТУРА

1. Кодекс Российской Федерации об административных правонарушениях от 30.12.2001 № 195-Ф3 (ред. от 31.07.2020) // Собрание законодательства РФ. 2002. № 1 (ч. 1). Ст. 1; 2020. № 31 (ч. 1). Ст. 5037.

2. Воздушный кодекс Российской Федерации от 19.03.1997 № 60-Ф3 (ред. от 08.06.2020) // Собрание законодательства РФ. 1997. № 12. Ст. 1383; 2020. № 24. Ст. 3740.

3. Постановление Правительства РФ от 25.05 .2019 № 658 «0б утверждении Правил учета беспилотных гражданских воздушных судов с максимальной взлетной массой от 0,25 килограмма до 30 килограммов, ввезенных в Российскую Федерацию или произведенных в Российской Федерации» // Собрание законодательства РФ. 2019. № 22. Ст. 2824.

4. Алексейчук А. Использование гражданских беспилотных летательных аппаратов: тонкости правового регулирования // ЭЖ-Юрист. 2019. № 25. [Эл. ресурс]. Режим доступа: https://www.eg-online.ru/article/401784 (дата обращения: 12.10.2020).

5. Большая российская энциклопедия, 2004 / Интернет-издание Министерства культуры Российской Федерации. [Эл. ресурс]. Режим доступа: https:// bigenc.ru/technology_and_technique/text/4087725 (дата обращения: 12.10.2020).

6. Виноградов И.А., Марчевский Н.К. 0 необходимости совершенствования мер по предупреждению киберпреступлений // Аллея науки. 2018. Т. 3. № 10.

7. Демидюк А.В., Фомин А.П. Дроны в городе: новые возможности или новые угрозы? // Системы безопасности. 2019. № 6. [Эл. ресурс]. Режим доступа: https://www.secuteck.ru/articles/drony-v-gorode-novye-vozmozhnosti-ili-novye-ugrozy (дата обращения: 12.10.2020).

8. Демуренко К.А. Дроны - новая угроза с высоты // Алгоритм безопасности. 2016. № 2.

9. Егоров И. Генпрокурор рассказал о росте числа киберпреступлений в России в 25 раз // Российская газета. 17.07.2020. [Эл. ресурс]. Режим доступа: https://rg.ru/2020/07/17/genprokuror-rasskazal-0-roste-chisla-kiberprestuplenij-v-rossii-v-25-raz (дата обращения: 12.10.2020).

10. Костин А.С., Богатов Н.В. Вопросы современного развития рынка беспилотных летательных аппаратов // Системный анализ и логистика. 2019 . № 4.

11. Краснов С.В., Малышев С.Р., Краснова С.А., Шишков В.А. Модель угроз от малогабаритных беспилотных летательных аппаратов // Вопросы оборонной техники. Серия 16: Технические средства противодействия терроризму. 2019. № 7-8.

12. Лакомов А.С. Киберпреступность: современные тенденции // Академическая мысль. 2019. № 2.

13. Марат Ж.-П. План уголовного законодательства / Пер. с фр. Н.С. Лапшиной, под ред. А.А. Герцензона. М.: Изд-во иностр. лит., 1951. [Эл. ресурс]. Режим доступа: https://istmat.info/files/uploads/28661/marat_plan-legislation-criminelle.pdf (дата обращения: 12.10.2020).

14. Петров И. Генштаб предупредил об угрозе «атак дронов» в любой точке мира // Российская газета. 11.01.2018. [Эл. ресурс]. Режим доступа: https:// rg.ru/2018/01/11/genshtab-predupredil-ob-ugroze-atak-dronov-v-liuboj-tochke-mira.html (дата обращения: 12.10.2020).

15. Репецкая А.Л. Преступность в России и проблемы ее предупреждения // Пролог: журнал о праве. 2014. Т. 2. № 3.

16. Рождественская Я. Коммерческие беспилотники перешли из теории в практику // Коммерсантъ. 01.12.2019. [Эл. ресурс]. Режим доступа: https://www. kommersant.ru/doc/4178421 (дата обращения: 12.10.2020).

17. Смирнов А.А. Криминогенные факторы, обуславливающие совершение преступлений // Сборник научных работ серии «Право». 2019. № 1.

18. Федоров А.А. Дрон, как потенциальное орудие убийства // Актуальные проблемы уголовного судопроизводства и криминалистики: Материалы Интернет-конференции Сибирского юридического университета, 2020. [Эл. ресурс]. Режим доступа: https://conf.siblu.ru/dron-kak-potencialnoe-orudie-ubiystva (дата обращения: 12.10.2020).

(с Гиба Владислав Владимирович (vlad-giba@mail.ru), Агапов Павел Валерьевич.

Журнал «Современная наука: актуальные проблемы теории и практики» 